\title{
Die Belydenis in hermeneutiese verband
}

\author{
APB Breytenbach
}

\section{INLEIDENDE OPMERKINGS}

Hierdie opskrif kan op verskillende maniere vertolk word. Om misverstand te voorkom is 'n nadere omskrywing nodig.

Die uitdrukking "die Belydenis" verwys na die tradisionele belydenis van die Reformatoriese Kerke soos dit verwoord is in die drie formuliere van eenheid naamlik die Nederlandse Geloofsbelydenis, die Heidelbergse Kategismus en die Dordtse Leerreëls ${ }^{1}$.

Die term "hermeneutiese" het 'n wye betekenisspektrum. Die woord hermeneutiek is in sommige akademiese kringe tot 'n dekade of twee gelede gebruik om die teorie van eksegese aan te dui. Huidiglik word dit gebruik in verband met die verstaansproses. Dit gaan nie meer in die eerste plek oor die verstaan van tekste nie, maar oor verstaan self. Die woord word in hierdie sin as vakterm naas die teologie ook gebruik in die filosofie, linguistiek, geskiedenis, ensovoorts. In die teologie kan dit ook weer verskillende nuanses hê. My opdrag was om onder hierdie opskrif hoofsaaklik aan twee sake aandag te gee naamlik: hoe het die Belydenis die Skrif verstaan? en watter invloed het die Belydenis op die Kerk se verstaan van die Skrif?

Met hierdie twee vrae is 'n baie wye veld aangesny. Vrae oor Skrifbeskouing, gesag en inspirasie van die Skrif is onmiddellik ter sake. Vanselfsprekend kan daar nie op al hierdie sake volledig ingegaan word nie maar die belangrikste fasette sal kortliks behandel word.

\section{DIE HERMENEUTIESE BENADERING IN DIE BELYDENIS}

Die Skrifhantering van die reformatore is aan ons almal seker redelik goed bekend. Hulle het basies die voorbeelde van Skrifhantering wat in die Nuwe Testament voorkom, nagevolg. Dit het neergekom op wat ons sou kan noem korrekte uitleg, woordelikse uitleg buite konteks en in ' $n$ mindere mate ook tipologiese en allegoriese uitleg. In 'n denkklimaat wat slagspreuke soos sola scriptura en sacra scriptura sui ipsius interpres opgelewer het, is dit nie verrassend nie. Dit is ook nie verrassend dat die Nuwe Testament se verstaan van die Ou Testament in die Hervorming eintlik hermeneutiese sleutels geword het waarmee die Skrif benader is nie. Hier kan ons veral dink aan 
die belofte-vervulling-skema wat toegepas is op die verhouding $\mathrm{Ou}$ Testament-Nuwe Testament. Verder het die gedagte wat in die Nuwe Testament na vore kom dat Christus op een of ander bedekte en skaduagtige wyse in die Ou Testament verkondig word, ook 'n hermeneutiese sleutel geword. Dit is deur Luther selfs tot ' $n$ beginsel vir die vasstelling van die kanon verhef.

As 'n produk van die Reformasie handhaaf die Belydenis ook 'n sterk Christosentriese en Christologiese Skrifbeskouing. (Met Christosentriese word bedoel dat die Bybel gelees word vanuit die geloof in Jesus Christus en deur die bril van die Nuwe Testament. Met Christologiese word bedoel dat daar in elke deel van die Bybel Christusverkondiging verwag en gesoek word). Artikel 25 van NGB stel dan ook:

\section{Artikel 25 Die wet in Christus vervul}

Ons glo dat die seremonies en sinnebeelde van die wet met die koms van Christus opgehou het en dat alle voorafskaduwing tot 'n einde gekom het. Die gebruik daarvan moet derhalwe onder die Christene afgeskaf word.

Die waarheid en inhoud daarvan bly nogtans vir ons in Christus Jesus bestaan: in Hom het hulle juis hulle vervulling.

Ons gaan ook nog voort om die getuienisse van die wet en die profete te gebruik om ons geloof in die evangelie te bevestig en ook om ons lewe in alle eerbaarheid in te rig tot eer van God en volgens sy wil.

Vir die Belydenis is die goddelike gesag van die Skrif ook 'n uitgemaakte saak. Hierdie gesag is nie geleë in die beslissing van die kerk nie en ook nie in die persoon van outeurs nie, maar in die werking van die Heilige Gees. Dit word soos volg onder woorde gebring:

\section{Artikel 3 Die geskrewe Woord van God}

Ons bely dat hierdie Woord van God nie deur die wil van 'n mens gestuur of voortgebring is nie, maar die heilige mense van God het dit, deur die Heilige Gees gedrywe, gespreek, soos die heilige Petrus sê (2 Pet. 1:21). God het daarna vanweë sy besondere sorg vir ons en ons saligheid sy knegte, die profete en apostels, beveel om sy geopenbaarde Woord op skrif te stel en Hy het self met sy vinger die twee tafels van die wet geskrywe.

Daarom noem ons sulke geskrifte die heilige en goddelike Skrif.

\section{Artikel 5 Die gesag van die heilige Skrif}

Ons aanvaar al hierdie boeke, en hulle alleen, as heilig en kanoniek om ons geloof daarna te rig, daarop te grond en daarmee te bevestig. 
Ons glo ook sonder twyfel alles wat daarin vervat is, nie soseer omdat die kerk hulle aanvaar en as sodanig beskou nie, maar besonderlik omdat die Heilige Gees in ons harte getuig dat hulle van God is. Hulle het ook die bewys daarvan in hulleself, aangesien selfs die blindes kan tas dat die dinge wat daarin voorspel is, plaasvind.

\section{Artikel 7 Die volkomenheid van die heilige Skrif}

Ons glo dat hierdie heilige Skrif die wil van God volkome bevat en dat alles wat die mens moet glo tot saligheid, genoegsaam daarin geleer word. Aangesien die hele wyse van die diens wat God van ons vereis, daarin uitvoerig beskrywe is, mag ook niemand, selfs nie die apostels nie, anders leer as wat ons reeds deur die heilige Skrif geleer word nie - ja, al was dit ook' $n$ engel uit die hemel, soos die apostel Paulus sê (Gal. 1:8).

En aangesien dit verbode is om iets by die Woord van God by te voeg of daarvan weg te laat (Deut. 12:32), blyk dit duidelik dat die leer daarvan heeltemal volmaak en in alle opsigte volledig is.

Ons mag geen geskrifte van mense, hoe heilig die mense ook al was, met die goddelike Skrif gelykstel nie; ook mag ons nie die gewoonte of die groot getalle of oudheid op opvolging van tye en persone of kerkvergaderingsbepalings en -besluite gelykstel met die waarheid van God nie, want die waarheid is bo alles ...

In breë trekke kan ons die Skrifbeskouing wat in die Belydenis neerslag gevind het, soos volg saamvat:

Die Skrif is die geopenbaarde Woord van God wat deur mense opgeteken is op sy bevel. Dit het goddelike gesag - nie omdat die kerk so besluit nie, maar op grond van die getuienis van die Heilige Gees. Hierdie gesag word bevestig deur die vervulling van voorspellings wat in die Skrif voorkom. Verder is Christus die sleutel tot die verstaan van die Ou en die Nuwe Testament. Die Ou Testament getuig op 'n verborge wyse van Hom en voorspel sy koms. Die Nuwe Testament verkondig sy koms en werk.

In die leer of doctrina wat in die Reformasie uit so 'n verstaan van die Skrif gegroei het, staan Christus ook sentraal: Die verlossing uit sonde vind alleen deur Christus plaas en wel deur die geloof in Hom. Die geloof in Christus is 'n gawe van God wat Hy op grond van sy genadige verkiesing, wek en versterk deur die werking van die Heilige Gees. Hierdie sentrale waarheid wat in die spreuke solus Christus, sola gratia en sola fide tot uitdrukking kom en wat eintlik maar korrelate van dieselfde insig is, is ook die tema en refrein in die Belydenis. 
Dit is bekend dat die reformatore hulle verstaan van die Skrif wat in die Belydenis verwoord is, uitgespreek het met heilige erns en met 'n oortuiging wat hulle met hulle lewens sou verdedig; maar dat hulle tog ook bewus was van die moontlikheid dat die Belydenis in die lig van meer kennis van die Skrif, gewysig kan word. Dit word nie net geïmpliseer deur die reformatoriese beginsel ecclesia reformata semper reformanda nie, maar dit is ook pertinent uitgespel in die Acta van die Waalse sinodes.

"By die aanvang van elke sinodesitting moet die geloofsbelydenis van die kerke van hierdie land (= die Nederlandse Geloofsbelydenis) gelees word sodat ons eenheid daaruit sal blyk en om te besluit of iets daarin verander of gewysig moet word"3.

\section{DIE HERMENEUTIESE FUNKSIONERING VAN DIE BELYDENIS IN DIE NEDERDUITSCH HERVORMDE KERK}

Die Nederduitsch Hervormde Kerk stel in artikel I van sy Wet en Bepalings dat hy hom grond op die Bybel as die Woord van God en dat sy belydenis in die drie formuliere van eenheid uitgedruk word. Dit word herbevestig in artikel XI en verder word ook gestel (4): "Die Kerk weer uit sy midde alles wat die belydenis weerspreek". Dit is nie heeltemal duidelik of "die belydenis" in die aangehaalde punt verwys na die belydenis dat Christus Hoof is van die Kerk en Heer van die wêreld (3), of dit verwys na "die belydenis van die vadere" (2) waaronder NGB, HK en DL, en of dit verwys na beide (punt 2 en 3 ) as synde dieselfde. In die lig van punt 1 in artikel XI is die laaste moontlikheid die waarskynlikste. Dit beteken dan dat alles wat die geloof in die Drie-enige God weerspreek (1) uit die Kerk geweer word en nie soseer dit wat die formulering van die belydenisskrifte weerspreek nie.

Verder is dit uit die Kerkwet duidelik dat die Belydenis nie as 'n onveranderlike grootheid beskou word nie (artikel XII), maar dat dit in die lig van Skriftuurlike gegewens gewysig kan word (vgl. ook Bepaling 75).

Amptelik is NGB, HK en DL dus die belydenis van die Hervormde Kerk. Trou aan die Belydenis en die gees van die Reformasie val die klem egter op die leer van die Belydenis en word die Skrif bo die Belydenis gestel (vgl. Bepaling 113). Dieselfde klem op die leer kom ook tot uitdrukking in die ondertekeningsformule:

\section{Ondertekeningsformule}

Ek/Ons, die ondergetekende(s), dienaar(s) van die Woord van God in die Nederduitsch Hervormde Kerk van Afrika, verklaar hiermee dat ek/ons die leer wat uitgedruk is in die formuliere 
van eenheid, naamlik die Nederlandse Geloofsbelydenis, die Heidelbergse Kategismus en die Dordtse Leerreëls, en wat in ooreenstemming is met die Woord van God, van harte onderskryf en getrou sal verkondig. Ek/Ons beloof verder om my/ons stiptelik te hou aan die orde wat neergelê is in die Wet en Bepalings van die Kerk en by oortreding daarvan my/ons te onderwerp aan die oordeel van die bevoegde kerklike vergaderings.

Deur hierdie formule te onderteken, verklaar ek/ons dat ek/ons vas oortuigd is en glo dat die leer wat in die formuliere van eenheid uitgedruk is, in volkome ooreenstemming met die Woord van God is.

Dat die klem in die Hervormde Kerk op die leer van die Belydenis val en nie op die minderbelangrike sake nie, word verder bewys deur die teologiese arbeid in die Kerk. Niemand het byvoorbeeld nog ooit beswaar gemaak daarteen dat die mosaïse outeurskap van die Pentateug betwyfel word op grond van die inherente getuienis van die Skrif nie. Dit weerspreek die formulering van die Belydenis omdat Moses daarin as die skrywer van die Pentateug voorgehou word. Dieselfde geld byvoorbeeld wanneer dit gaan oor die outeurskap van die Dawidiese Psalms en sommige van die Pauliniese briewe. Die blote feit dat verskillende artikels wat ' $n$ histories-kritiese hantering van die Bybel voorstaan in Die Hervormer verskyn sonder dat dit beroering veroorsaak by die kerklike publiek, bewys dat dit nie net ' $n$ tendens by akademici is nie.

Te oordeel na oordenkings en preke van predikante in kerkblaaie en oor die radio geld die leer van die Belydenis nog steeds as riglyn vir die verstaan van die Skrif. Ten opsigte van die hantering van die Skrif is daar egter voorbeelde wat heel uiteenlopend van aard is. Sommige predikante sal gebruik maak van aanhalings buite konteks, tipologie en selfs ook allegorie in hulle hermeneutiese hantering van veral die Ou Testament. Soos in die Belydenis is daar by die meerderheid predikante in mindere of meerdere mate ook 'n Christologiese en Christosentriese verstaan van die Skrif te bespeur.

Hierteenoor kan gevalle aangehaal word waar preke van hervormde kansels af in 'n sekere sin lynreg staan teenoor 'n Christologiese verstaan van die Ou Testament en waarin buitekontekstuele en tipologiese hermeneuse by implikasie gekritiseer word.

Samevattend sou ons kon sê dat die Belydenis hermeneuties baie sterk funksioneer as riglyn wanneer dit gaan oor die leer in die Skrif. Dit dien dan ook in hierdie opsig as maatstaf vir die ouderlinge om te bepaal of die Skrif korrek vertolk is. Die Belydenis sal beslis ook as norm aangelê word in geval van 'n tugsaak wat oor die leer handel.

Ten opsigte van minder belangrike sake, en veral wanneer dit kom 
by die hermeneutiese hantering van die Skrif, dien die Belydenis deurgaans nie as riglyn nie. In die praktyk word die predikante se beoefening van hermeneutiek feitlik sonder uitsondering bepaal deur elkeen se akademiese skoling en nie deur die Belydenis nie.

\section{ENKELE PROBLEME}

Die saak is egter nie so eenvoudig as wat dit tot dusver mag klink nie. Die leer of essensiële sake in die Belydenis is nie altyd waterdig te skei van die minder belangrike sake nie. Daar is nie net raakpunte tussen essensiële en minder belangrike sake nie; daar is inderdaad 'n grys gebied waar die lyne nie altyd so duidelik getrek kan word nie. Kan 'n saak soos die Skrifbeskouing, wat in die Belydenis absoluut 'n sentrale plek inneem, byvoorbeeld as nie-essensieel geklassifiseer word? Dit lyk nie moontlik nie. Kan hierdie Skrifbeskouing nog ongekwalifiseerd onderskryf word deur al die leraars? Indien nie, op watter stadium moet 'n gravamen ingedien word? Watter kans is daar dat so 'n gravamen sal slaag? Die Belydenis kan de iure gewysig word, maar de facto het dit 'n posisie verkry wat 'n wysiging feitlik onmoontlik sal maak.

'n Probleem wat met die voorafgaande saamhang is die vraag hoe wyd die grense getrek kan word wanneer dit gaan oor Skrifbeskouing en Skrifhantering? Verskil van opinie is altyd vrugbaar vir studie en veral vir teologiese studie. Maar is dit nog vrugbaar en is dit ' $n$ duldbare verskeidenheid wanneer lidmate van dieselfde kerk met dieselfde belydenis mekaar oor en weer verdink en selfs beskuldig van uiterste fundamentalisme aan die een kant, en uiterste teologiese liberalisme aan die ander kant?

Daar is al gesuggereer dat die oplossing vir hierdie probleme lê by ' $n$ nuwe belydenis wat die heilswaarhede van die Skrif in ' $n$ byderwetse idioom verwoord. Hierteenoor wil ek die volgende stel:

1. 'n Belydenis word nie sommer "gemaak" nie, maar onstaan altyd in 'n polemiese situasie wat krisisafmetings begin aanneem. Op die oomblik is dit nie die geval by ons nie.

2. Een van die belangrikse funksies van ' $n$ belydenis is om die band van eenheid tussen geloofsgenote te versterk. 'n Nuwe belydenis sou op hierdie stadium eerder groter verdeeldheid as eenheid bring.

3. Enige nuwe belydenis sal tydgebonde wees en sal binne 10 jaar agterhaal wees in ' $n$ vinnig veranderende teologiese klimaat.

Die enkele probleme wat aangesny is, sal opgelos moet word ter wille van die kerk se getuienistaak in die wêreld en ter wille van die kerk se ekumeniese gesprek. As die ampsdraers van die kerk nie 
eenheid kan vind om 'n gemeenskaplike belydenis nie, sal daar nie met oortuiging teenoor die wêreld getuig kan word van die waarheid van die Woord nie.

In die soeke na antwoorde op hierdie probleem, sal daar begin moet word by die vraag: wat behoort die funksie van die Belydenis te wees in 'n moderne wêreld? Of nog duideliker gestel: hoe behoort die tradisionele Belydenis wat in ' $n$ bepaalde historiese milieu ontstaan het, hermeneuties te funksioneer in ' $n$ kerk wat in sy teologiese arbeid nie terugdeins vir die resultate van die histories-kritiese Bybelwetenskap nie?

\section{Verwysings}

1. Verder afgekort as NGB, HK en DL. Aanhalings hieruit word in Afrikaans gegee uit die voorlopige proefvertaling van die Interkerklike Kommissie.

2. Vgl sy bekende spreuk "Was Christum treibet".

3. AD Pont, Die Historiese Agtergronde van ons Kerklike Reg, Pretoria 1981, bl 62. 